\title{
The Japanese Thoughts on Twelver Shia
}

\author{
Prixton Church \& University
}

2020

\section{References}

[1] Tahara, Hiroki. (2020). Why the Persians Accepted Twelverism -Research Focusing on the Description in the History of the Prophets and Kings-. Journal of Humanities and Social Science, 25.(7.6), 39-40.

[2] Tahara, Hiroki. (2019). Methodology to Prove the Quranic Correctness. International Journal of Humanities and Social Science Invention, 8.(10.1), 01-02.

[3] Bill, J. A., \& Williams, J. A. (2002). Roman Catholics and Shi'i Muslims: Prayer, Passion, and Politics. University of North Carolina Press.

[4] van den Bos, M. E. (2020). Shiite Patterns of Post-Migration in Europe. Islam and Christian-Muslim Relations, 31(1), 1-22.

[5] Scharbrodt, O. (2020). Creating a Diasporic Public Sphere in Britain: Twelver Shia Networks in London. Islam and Christian-Muslim Relations, 31(1), 23-40.

[6] 杉山隆一. (2020). アフシャール 朝期のイマーム・レザー廟: 『アリー・シャーの巻物』から見る一八世紀イランにおけるイマーム廟 の運営と組織 (I). 東洋文化研究所紀要=The memoirs of Institute for Advanced Studies on Asia, 177, 230-178.

[7] 中村友一. (2020). ムスリム NGO と地域紛争: タジキスタン・山岳バダフシャ ン自治州の事例.

[8] 深見和子. (2020). 近代イランの植物学的研究一東洋文庫所蔵 A. ガフレマー ン著植物写真集『イラン植物誌 (Flore de l'Iran)』について一. 東洋文庫書報, (51), 79-99.

[9] 四日市康博. (2020). 声と色から読み解く歴史文書学: イランのモンゴル帝国 期命令文書から. 史苑, 80(2), 1-13.

[10] 武井由紀. (2020). <<journalistique >> と呼ばれるフランス語条件法の解釈 について. 名古屋外国語大学論集, (6), 81-96. 
[11] 井上克人. (2020). 澤井義次・鎌田繁編『井筒俊彦の東洋哲学』. 宗教哲学研究, $37,114-117$.

[12] 平野貴大. (2020). Hussein Ali Abdulsater, Shi'i Doctrine, Mu'tazili Theology: al-Sharif al-Murtada and Imami Discourse. イスラム思想研究，2, 129-135.

[13] 木 村風雅. (2020). サラー フッディーン・アラーイー 『随行の高貴さが確立される者の階級の卓越性の解明』解題・訳 注. イス ラム思想研究, $2,109-128$.

[14] 西山尚希. (2020). イブン・タイミーヤ著『スンナの道』第 3 章第 1 節翻訳 (1). イスラム思想研究, 2, 91-108. 